\title{
The reaction of mountain glaciers to climatic change under continental conditions
}

\author{
M. G. Kunakhovitch, A. M. Sokalskaya \\ Laboratory of Mountain Glaciology, Institute of Geography, Russian Academy of Sciences, Staromonetny 29, Moscow 109017, Russia
}

\begin{abstract}
Data on the distribution of accumulation with elevation were used to calculate ablation, internal accumulation, annual mass balance and glacier runoff for the Tien Shan glaciers with a total area of about $15500 \mathrm{~km}^{2}$. The altitudinal profile of normalized ablation is approximated by an exponential curve. Mass-balance components and glacier runoff are calculated for the whole possible range of glacier equilibrium-line positions in the major river and lake basins of the Tien Shan.

For steady state it was found that the equilibrium line rises from $3600 \mathrm{~m}$ in western areas to $4400 \mathrm{~m}$ in the east, whilst the accumulation area ratio and glacier runoff increase eastward from $63 \%$ to $71 \%$, and from 600 to $1200 \mathrm{~mm}$, respectively. Losses of meltwater runoff for internal accumulation average 7\% $(5-11 \%)$.

In abnormally warm years, mass balance may reach $-2300 \mathrm{~mm}$ w.e. in the west and $-855 \mathrm{~mm}$ in the east and in the internal Tien Shan (Khan Tengry massif). Glacier runoff volume in those years has been estimated at $40 \mathrm{~km}^{3} \mathrm{year}^{-1}$, which is 2.5 times as large as for the steady state.
\end{abstract}

\section{INTRODUGTION}

The Tien Shan is a very complicated mountain system in Central Asia with more than $16000 \mathrm{~km}^{2}$ glacierization and about 16000 different glaciers. The high mountain areas of the Tien Shan feed the major rivers of Central Asia and closed drainage basins of the Aral Sea, Lake Balkhash and Issyk-Kul. Glacier runoff contributes $20-80 \%$ (Tarim river basin) to the total runoff of these arid regions in summer months (July-August). As mass balance is regularly measured on only a few small glaciers of the study area, it is a challenge to estimate it for the whole glacierization of the Tien Shan or separate large river and lake basins. To solve the problem, we used the calculation method that was applied to the part of the Tien Shan on the territory of the former Soviet Union (Dyurgerov and others, 1992). The completion of glacier inventories for the whole Tien Shan (Central Asian republics and China) made this possible.

\section{METHODS}

The whole Tien Shan mountain system is a large area without external runoff. There are seven interior basins: the Aral Sea, Lake Balkhash, and Issyk-Kul, the rivers Tarim, Chu and Djungarskaya (part of the Ily river system) and Tourfan-Khami depressions. All these basins are located in different orographic and climatic environments. Within these major areas there are 310 glaciated river basins with similar snow accumulation and ablation conditions. Consider glacierization in each basin as a large hypothetic glacier covering the area in the whole altitudinal range where real glaciers are located with all the possible aspects (Dyurgerov, 1986). Such a glacier can be characterized by the vertical profiles of the glaciated area and snow accumulation, because altitude is the main parameter of mass-balance variation.

Data from the USSR glacier inventory (Akademii Nauk SSSR, 1969-78; Kuzmichenok, 1993) and China glacier inventory (Academia Sinica, 1986-87) were used to build glacier hypsographic curves. To estimate snow accumulation we used winter mass-balance measurements on glaciers and snow accumulation over meteorological stations all over the Tien Shan (Getker, 1985). Statistical analysis of all available data enabled us to divide the Tien Shan area into 22 basins with similar accumulation distribution with elevation within each basin.

As the ablation depends on many different climatic and orographic factors it is not possible at present to calculate it for the whole mountain system. Khodakov (1965), and later Krenke and Menshutin (1987), showed that different mor-

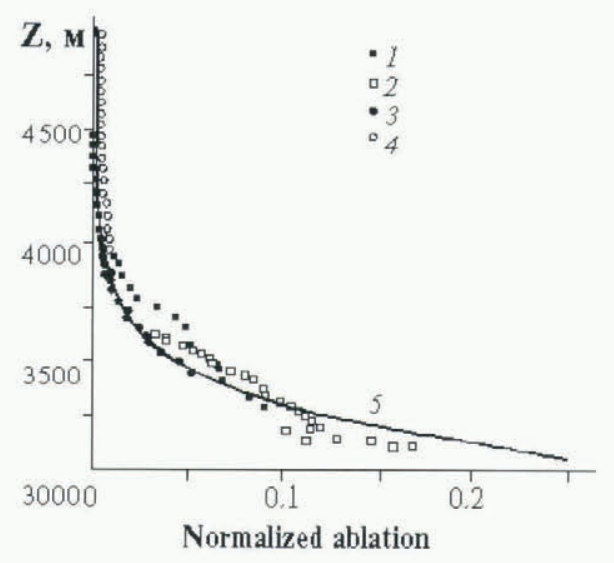

Fig. 1. The distribution of normalized ablation with altitude. Observed data for glaciers 1, Sary Tor; 2, Shumskogo; 3, Davydova; 4, Golubina. 


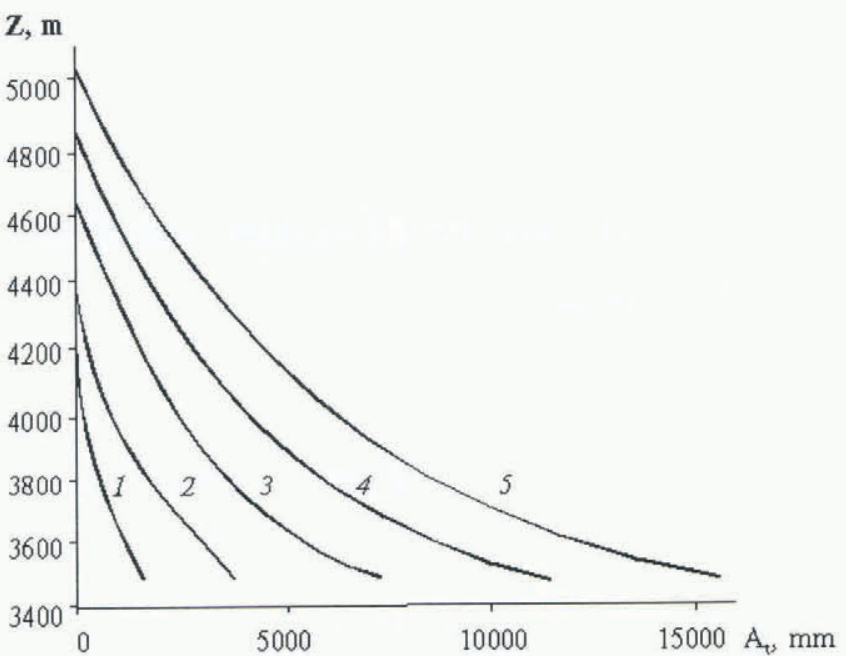

Fig. 2. The distribution of ablation over altitude for different ELA positions: $1,3850 \mathrm{~m} ; 2,4050 \mathrm{~m} ; 3,4250 \mathrm{~m} ; 4,4450 \mathrm{~m} ; 5$, $4650 \mathrm{~m}$.
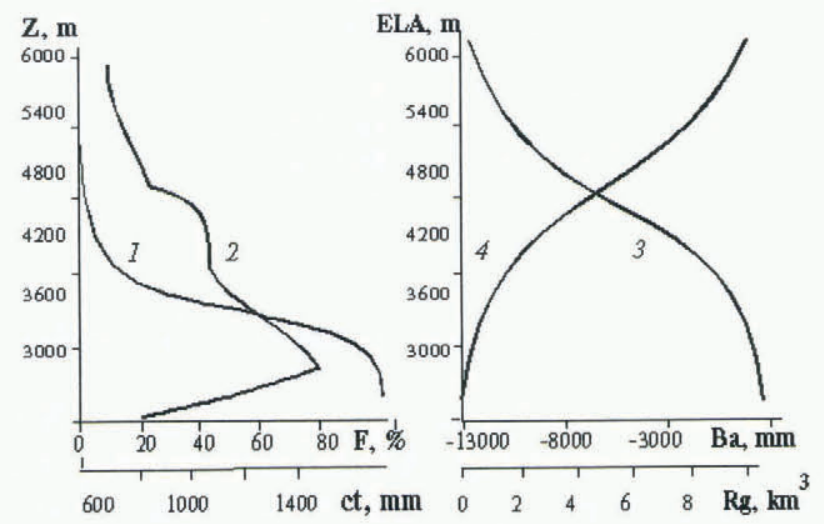

Fig. 3. The distribution of glacier area (1) and accumulation (2) with altitude (Z), and the relations of mass balance (3) and glacier runoff (4) with the ELA for the northern slope of Zailyiskyi Alatau range. phologic types of glaciers are characterized by similar distribution of ablation with elevation. We found out that normalized (0-1) ablation values for different Tien Shan glaciers can be closely described by the concave curve (Kunakhovitch, 1991) (Fig. 1):

$$
a_{\mathrm{t} i}=v \mathrm{e}^{-k z_{i}},
$$

where $i$ is the number of the altitude zone, and $z_{i}$ is normalized $(0-1)$ altitude:

$$
z_{i}=\frac{Z_{i}-Z_{\min }}{Z_{\max }-Z_{\min }}
$$

where $Z_{\min }$ and $Z_{\max }$ are the lower and upper levels of the Tien Shan glacierization, $Z_{i}$ is the average altitude of each interval, and $v$ and $k$ are empirical coefficients. The coefficient $k=10$ was calculated from data from field observations on glaciers.

Thus, we need the value of ablation in only one elevation zone in order to determine the ablation distribution with altitude for the whole basin. The highest equilibrium-line altitude (ELA) at the end of summer seems to be the best choice of the elevation zone $i$. The ablation here is equal to the accumulation: $a(\mathrm{ELA})=c(\mathrm{ELA})$.

Using Equation (1), the coefficient $v$ can be expressed as:

$$
v=c_{\mathrm{t}}(\mathrm{ELA}) / \mathrm{e}^{k z(\mathrm{ELA})} .
$$

The coefficient $v$ varies during the ablation season and depends on the position of the equilibrium line as shown in Figure 2. Mass-balance values $b_{\mathrm{n} i}$ in each interval $i$ were estimated as differences between accumulation and ablation for each ELA:

$$
b_{\mathrm{n} i}=c_{\mathrm{t} i}-v \mathrm{e}^{-k z_{i}} .
$$

We use these three curves (ablation, accumulation and hypsographic) for computation of snow ablation, mass balance and glacier runoff for different equilibrium-line positions.

$$
B_{\mathrm{n}}=\sum_{i=1}^{n}\left(c_{\mathrm{t} i}-v \mathrm{e}^{-z_{\mathrm{i}} k}\right) \frac{s_{i}}{S}
$$

where $S$ is the total glaciated area, represented by the hyp-
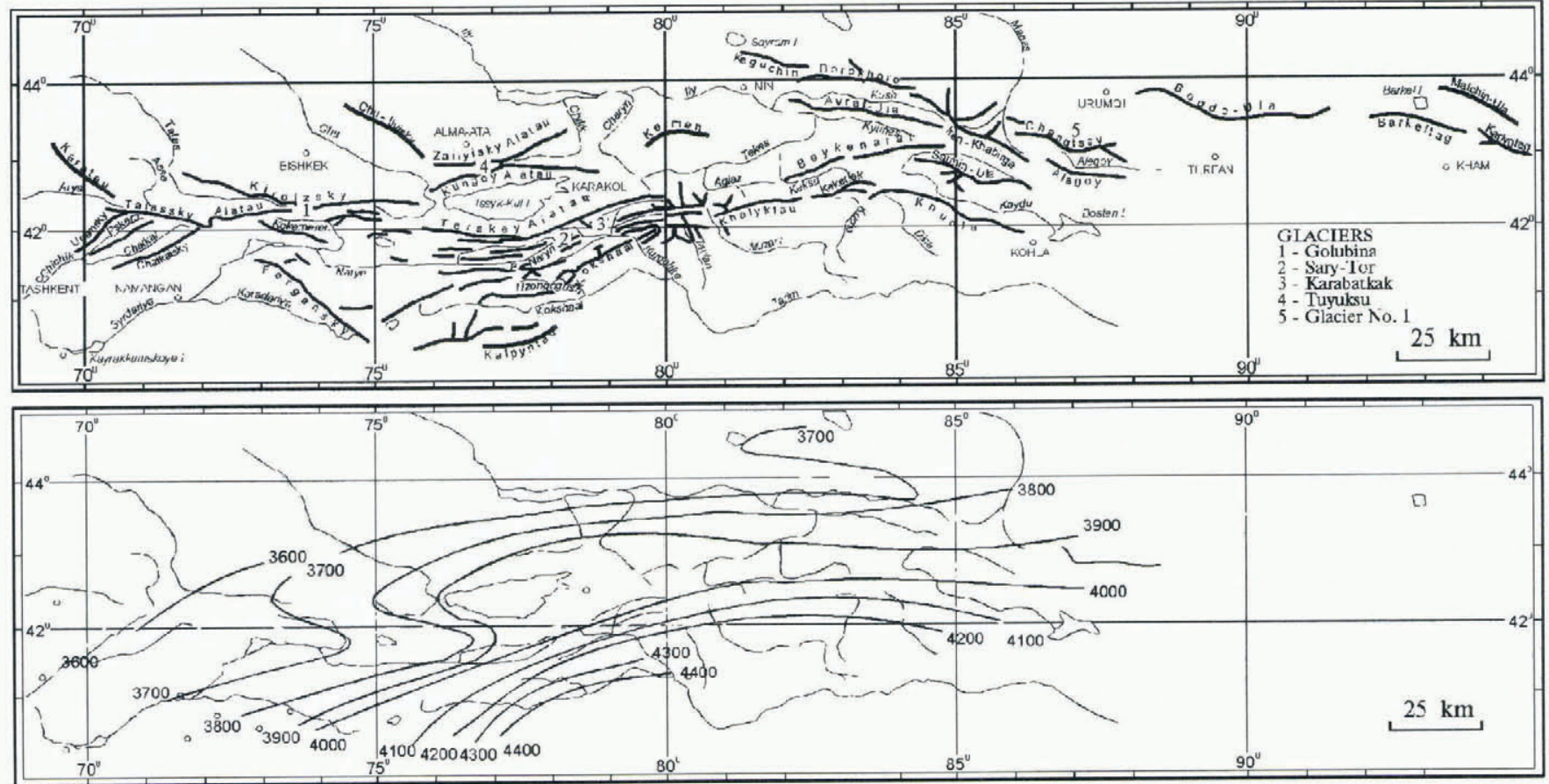

Fig. 4. The distribution of ELA over the Tien Shan in steady-state conditions. 
Table 1. The main characteristics of glaciated basins in steady state

\begin{tabular}{|c|c|c|c|c|c|c|c|}
\hline \multirow[t]{2}{*}{ Glaciated basin } & \multirow{2}{*}{$\begin{array}{c}\text { Glaciated area } \\
\mathrm{km}^{2}\end{array}$} & \multirow{2}{*}{$\begin{array}{c}A A R \\
\%\end{array}$} & \multirow{2}{*}{$\begin{array}{c}E L A \\
\mathrm{~m}\end{array}$} & \multirow{2}{*}{$\begin{array}{c}a_{\mathrm{t}} \\
\mathrm{mm}\end{array}$} & \multirow{2}{*}{$\begin{array}{c}R_{\mathrm{g}} \\
\mathrm{km}^{3}\end{array}$} & \multicolumn{2}{|c|}{ Internal accumulation } \\
\hline & & & & & & $\mathrm{mm}$ & $\%$ \\
\hline Upper Naryn & 975 & 64 & 4167 & 771 & 0.75 & 43 & 5 \\
\hline Naryn & 137 & 64 & 3696 & 1251 & 0.17 & 86 & 6 \\
\hline Karadarya & 113.7 & 63 & 4068 & 846 & 0.1 & 51 & 6 \\
\hline Atbashy & 179 & 65 & 3614 & 1590 & 0.28 & 97 & 6 \\
\hline Chirchik & 179 & 65 & 3614 & 1590 & $\underline{0.28}$ & 97 & 6 \\
\hline Sum & & & & & $\overline{2.31}$ & & \\
\hline Chu & 635 & 63 & 3829 & 946 & 0.6 & 53 & 5 \\
\hline Upper Chu & 107 & 64 & 3924 & 721 & 0.08 & 21 & 3 \\
\hline Talas & 165 & 65 & 3675 & 389 & $\underline{0.15}$ & 55 & 6 \\
\hline Sum & & & & & $\overline{0.83}$ & & \\
\hline West Issyk-Kul & 344.8 & 63 & 3961 & 616 & 0.21 & 45 & 7 \\
\hline East Issyk-Kul & 358.4 & 63 & 3919 & 1213 & $\underline{0.43}$ & 98 & 7 \\
\hline Sum & & & & & $\overline{0.65}$ & & \\
\hline Sary Djus & 2465 & 68 & 4203 & 894 & 2.2 & 98 & 10 \\
\hline Aksay & 2202 & 65 & 4298 & 702 & 1.55 & 65 & 8 \\
\hline Kokshaal & 292 & 62 & 4469 & 580 & 0.17 & 47 & 8 \\
\hline Kumalike & 2873 & 71 & 3709 & 885 & 2.54 & 91 & 9 \\
\hline Muzart & 1784 & 68 & 4189 & 1081 & 1.93 & 111 & 9 \\
\hline Sum & & & & & $\overline{8.39}$ & & \\
\hline Keksu & 422 & 65 & 3800 & 978 & 0.41 & 81 & 8 \\
\hline Kash & 422 & 64 & 3661 & 1106 & 0.47 & 90 & 8 \\
\hline Kunes & 96.7 & 67 & 4285 & 926 & 0.09 & 41 & 4 \\
\hline Tekes & 1023.9 & 66 & 3893 & 935 & 0.96 & 100 & 10 \\
\hline Ily & 723 & 61 & 3883 & 1273 & $\underline{0.92}$ & 106 & 8 \\
\hline Sum & & & & & $\overline{2.85}$ & & \\
\hline Kaidu & 444.5 & 63 & 3950 & 820 & 0.36 & 59 & 7 \\
\hline Sairan & 637 & 63 & 3741 & 779 & 0.5 & 71 & 8 \\
\hline Average/sum & 17368 & 65 & 3955 & 947 & 15.88 & 74 & 7 \\
\hline
\end{tabular}

sographic curve, $s_{i}$ is the area of altitudinal zone $i$, and $n$ is the number of elevation intervals. Glacier runoff $R_{\mathrm{g}}$ is supposed to be equal to integrated ablation, assuming negligibly small evaporation in summer. Thus, using the data of two curves $c_{\mathrm{t}}(Z)$ and $s(Z)$ we found the relationships $b_{\mathrm{n}}=f($ ELA $)$ and $R_{\mathrm{g}}=f($ ELA) for each of the 22 basins (Fig. 3). Below, the results for steady-state and extremal conditions are presented.

\section{RESULTS}

\section{(1) Steady-state condition; glacier mass balance equals zero and area is constant}

We calculated the ELAs in each basin according to the above technique for these conditions.
The ELA spatial distribution is shown in Figure 4. Difference in ELA reaches $900 \mathrm{~m}$ within the Tien Shan area. It increases from $3600 \mathrm{~m}$ a.s.l. in the lowest western and northern parts to $4500 \mathrm{~m}$ in the south, where mountains are much higher (Table 1). Another factor responsible for ELA location is the precipitation amount. Thus, heavy precipitation over the northern and western windward ranges also accounts for low altitudes of glacier equilibrium line in this region.

In the internal Tien Shan the number of glaciers that are located on the windward peripheral slopes and get large amounts of precipitation is one-third of that of glaciers in large valleys which are usually colder and shielded from the main moisture-carrying air streams.

The accumulation area ratio (AAR) is $60 \%$ in the west peripheral part of the Tien Shan and reaches $70 \%$ in the

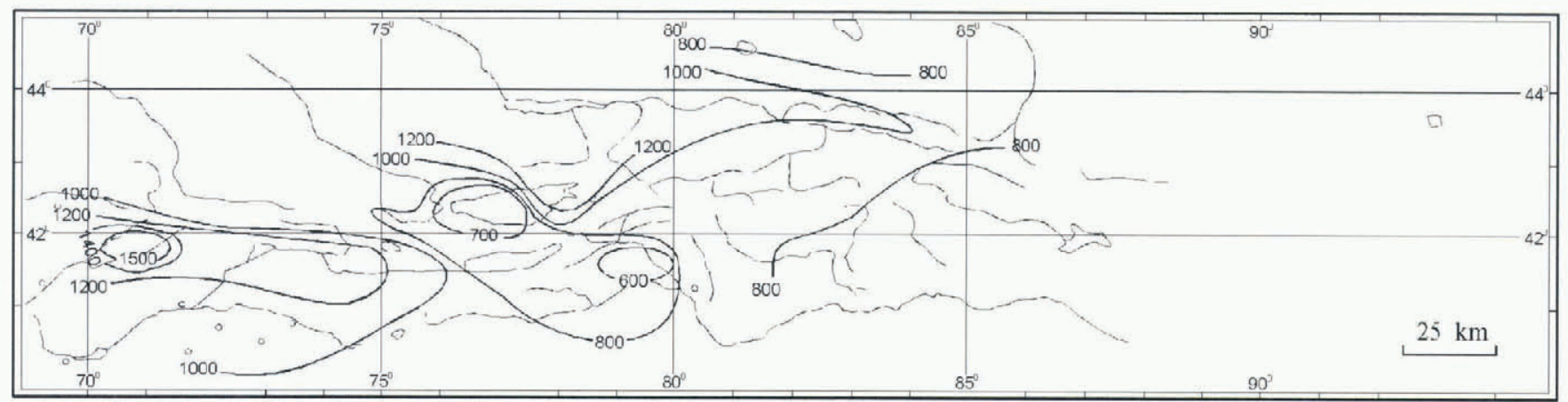

Fig. 5. The distribution of specific glacier runoff $(\mathrm{mm})$ over the Tien Shan in steady-state conditions. 
Table 2. The extremal values of the glaciated basins

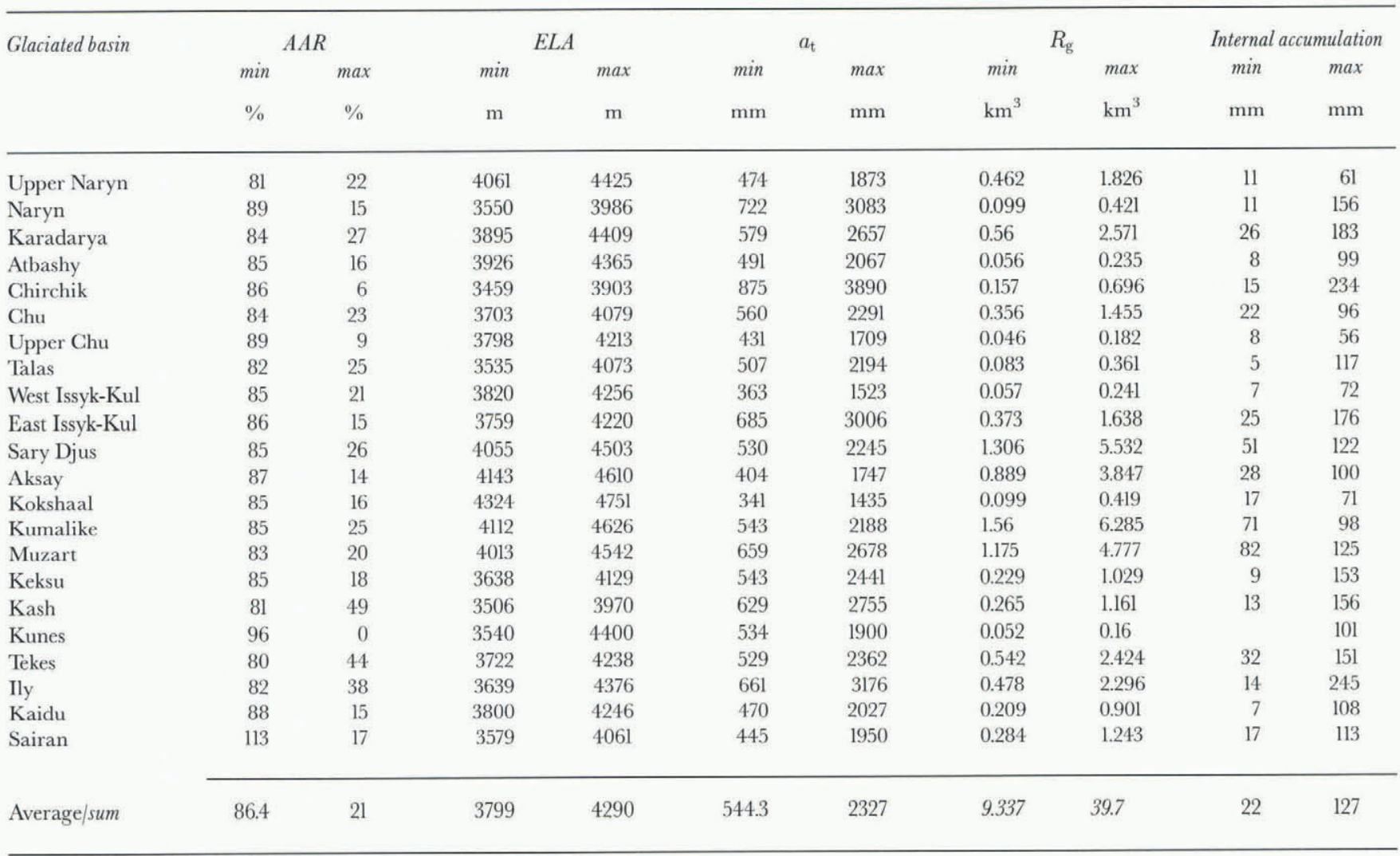

internal and eastern regions. The range of variations in AAR is similar in the Alps. It is worth noting that glaciers with smaller AAR have greater balance gradients for a given topography or hypsometric curve. The average massbalance gradient for the whole Tien Shan at the ELA level makes up $2.7 \mathrm{~mm} \mathrm{~m}^{-1}$, varying from $1.6 \mathrm{~mm} \mathrm{~m}^{-1}$ in the western and northern areas to $4.4 \mathrm{~mm} \mathrm{~m}^{-1}$ in the south. Our results differ from those obtained by Kuhn and others (1985) for Kesselwandferner and Hintereisferner, Austrian Alps. The difference may be accounted for by the local topographic peculiarities of these two glaciers. It can be concluded that to maintain steady state a glacier with a relatively low accumulation needs a greater accumulation area.

Assuming glacier runoff, $R_{\mathrm{g}}\left(\mathrm{km}^{3}\right)$, equal to integrated ablation, it is evident that in steady state $a_{\mathrm{t}}=c_{\mathrm{t}}$. So the distribution of $r_{\mathrm{g}}$ specific values is the same as that of precipitation (see Fig. 5). Specific $r_{\mathrm{g}}$ increases northwestward from a low of $580 \mathrm{~mm}$ in the southern part of Kokshaal river to
$1100-1600 \mathrm{~mm}$ in the Chirchik river basin and on the northern slope of the Zailyiskyi Alatau range. The amount of internal glacier accumulation makes up $5-8 \%$ of the total ablation on the north and west peripheral ranges and may exceed $10 \%$ in the interior of the Tien Shan.

In steady state, Tien Shan glaciers contribute about $15 \mathrm{~km}^{3}$ which is $7-40 \%$ of the total annual runoff of the biggest Central Asian rivers. The glaciers contribute more than $2 \mathrm{~km}^{3}$ of fresh water to the Aral Sea, about $3 \mathrm{~km}^{3}$ to Lake Balkhash and $0.6 \mathrm{~km}^{3}$ to Issyk-Kul each year.

\section{(2) Extremal conditions}

The range of year-to-year ELA variations is about 400$600 \mathrm{~m}$. In low river basins such as Chirchik and Chu (Ily) where in years with heavy precipitation the ELA can descend as low as $3450-3550 \mathrm{~m}$, it can rise as high as $3900 \mathrm{~m}$ in dry years. In the highest part of the mountain system

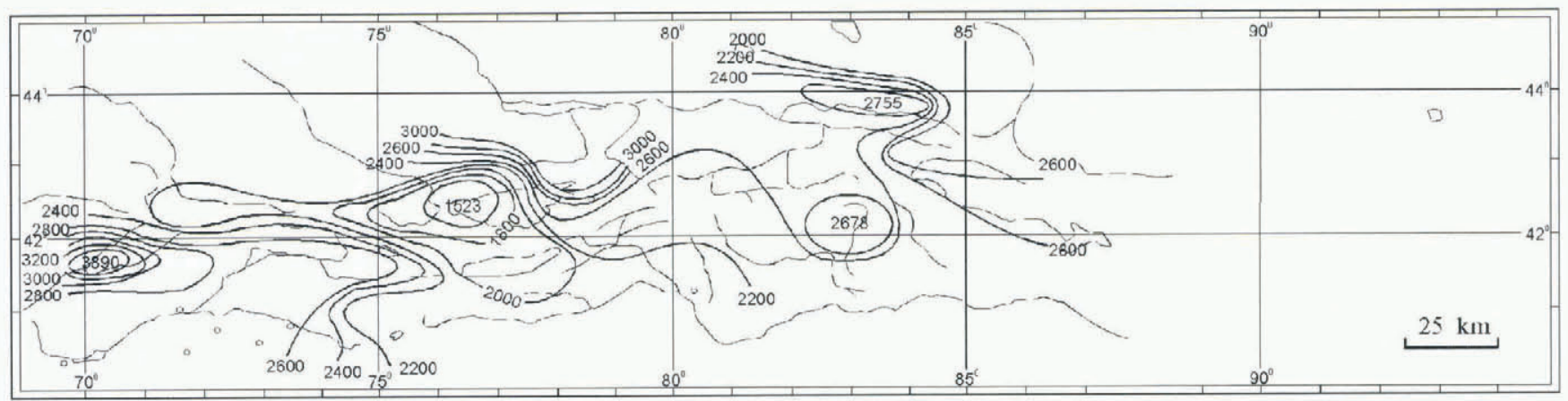

Fig. 6. The distribution of maximum glacier runoff (specific values, $\mathrm{mm}$ ) over the Tien Shan in extremely warm years, or in lowest ELA position. 


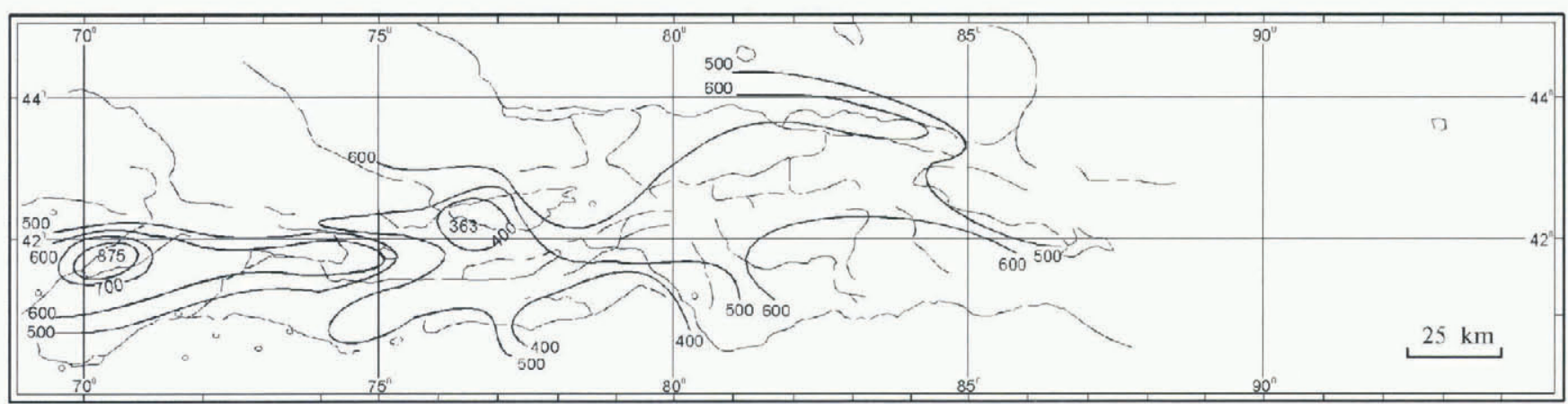

Fig. 7. The distribution of minimum glacier runoff (specific values, $\mathrm{mm}$ ) over the Tien Shan in extremely cold years, or in highest ELA position.

(Khan Tengry area) the ELA varies from 4050 to $4600 \mathrm{~m}$ under different meteorological conditions (Table 2).

In high-accumulation years when the AAR on peripheral ranges of the Tien Shan is nearly $90 \%$, mass balance can reach $700 \mathrm{~mm}$ and glacier runoff about $870 \mathrm{~mm}$. The refreezing of meltwater within deep snowpack is also greater in extremal years (positive mass balance), comprising $200 \mathrm{~mm}$, or about $20 \%$ of annual ablation. In more continental areas, $b_{n}$ and $R_{\mathrm{g}}$ never exceed 400 and 340$600 \mathrm{~mm}$, respectively (Fig. 6). But the total area of glaciers in these areas is very significant; only the glaciers of Khan Tengry can produce more than $4 \mathrm{~km}^{3}$ of water per year.

In extremely warm years mass balance may reach $-2300 \mathrm{~mm}$ on the western and northern glaciers. This results in $R_{\mathrm{g}}$ of nearly $4000 \mathrm{~mm}_{\text {year }}{ }^{-1}$ (Fig. 7). Thus glaciers lose three times more water than in extremely cold years. The glacier runoff from high internal regions (Khan Tengry, Ak-Shiyrak, Kokshaal, etc.) does not exceed $860 \mathrm{~mm}$ even in extremely warm years (Fig. 6).
The possible reaction of mass balance of the Tien Shan glaciers to climatic changes is shown in Table 3. An increase of $1{ }^{\circ} \mathrm{C}$ in summer temperature would reduce the AAR by $10 \%$ in the Ily river basin (we use this basin as the key area because of the extensive climatic parameters and massbalance data available). For example, if the mean summer temperature increased by $1{ }^{\circ} \mathrm{C}$, the mass balance would change by up to $-400 \mathrm{~mm}$ in the Issyk Kul, Chu and Talas basins.

\section{CONCLUSION}

Our emphasis has been on calculations of mass balance and glacier runoff for large areas. But it is evident that these estimates should be tested against actual observation data. However, standard hydrological data may be used to test the calculated glacier runoff only for separate basins with a glacial area of more than $50 \%$. Only a few records on

Table 3. The mass balance of basins under different climatic conditions

\begin{tabular}{|c|c|c|c|c|c|c|c|c|c|}
\hline \multirow[t]{2}{*}{ Glaciated basin } & \multicolumn{9}{|c|}{$A A R$ in Ily basin (\%) } \\
\hline & 10 & 20 & 30 & 40 & 50 & 60 & 70 & 80 & 90 \\
\hline Upper Naryn & -1101 & -601 & -385 & -234 & -114 & 6 & 95 & 191 & 297 \\
\hline Naryn & -1832 & -1022 & -665 & -411 & -209 & -11 & 173 & 342 & 529 \\
\hline $\begin{array}{l}\text { Karadarya } \\
\text { Atbashy } \\
\text { Chirchik }\end{array}$ & $\begin{array}{l}-1621 \\
-1222 \\
-2299\end{array}$ & $\begin{array}{r}903 \\
-679 \\
-1276\end{array}$ & $\begin{array}{l}-583 \\
-436 \\
-830\end{array}$ & $\begin{array}{r}-355 \\
-263 \\
-510\end{array}$ & $\begin{array}{l}-174 \\
-128 \\
-257\end{array}$ & $\begin{array}{r}-9 \\
-7 \\
-13\end{array}$ & $\begin{array}{l}147 \\
110 \\
217\end{array}$ & $\begin{array}{l}296 \\
222 \\
443\end{array}$ & $\begin{array}{r}457 \\
355 \\
716\end{array}$ \\
\hline $\begin{array}{l}\text { Chu } \\
\text { Upper Chu } \\
\text { Talas }\end{array}$ & $\begin{array}{r}-1344 \\
-988 \\
-1299\end{array}$ & $\begin{array}{r}-737 \\
-543 \\
-717\end{array}$ & $\begin{array}{l}-474 \\
-352 \\
-459\end{array}$ & $\begin{array}{r}-289 \\
-215 \\
-276\end{array}$ & $\begin{array}{l}-144 \\
-107 \\
-135\end{array}$ & $\begin{array}{l}-8 \\
-6 \\
-7\end{array}$ & $\begin{array}{r}123 \\
90 \\
115\end{array}$ & $\begin{array}{r}244 \\
179 \\
244\end{array}$ & $\begin{array}{l}386 \\
290 \\
388\end{array}$ \\
\hline $\begin{array}{l}\text { West Issyk-Kul } \\
\text { East Issyk-Kul }\end{array}$ & $\begin{array}{r}-906 \\
-1794\end{array}$ & $\begin{array}{l}-504 \\
-987\end{array}$ & $\begin{array}{l}-328 \\
-639\end{array}$ & $\begin{array}{l}-204 \\
-390\end{array}$ & $\begin{array}{l}-100 \\
-193\end{array}$ & $\begin{array}{r}-5 \\
-10\end{array}$ & $\begin{array}{r}82 \\
163\end{array}$ & $\begin{array}{r}162 \\
329\end{array}$ & $\begin{array}{l}254 \\
527\end{array}$ \\
\hline $\begin{array}{l}\text { Sary Djus } \\
\text { Aksay } \\
\text { Kokshaal } \\
\text { Kumalike } \\
\text { Muzart }\end{array}$ & $\begin{array}{r}-1350 \\
-1045 \\
-855 \\
-1302 \\
-1596\end{array}$ & $\begin{array}{l}-742 \\
-575 \\
-471 \\
-710 \\
-869\end{array}$ & $\begin{array}{l}-476 \\
-368 \\
-303 \\
-454 \\
-557\end{array}$ & $\begin{array}{l}-290 \\
-224 \\
-186 \\
-275 \\
-338\end{array}$ & $\begin{array}{r}-143 \\
-111 \\
-91 \\
-134 \\
-165\end{array}$ & $\begin{array}{l}-7 \\
-6 \\
-5 \\
-7 \\
-8\end{array}$ & $\begin{array}{r}118 \\
91 \\
76 \\
111 \\
137\end{array}$ & $\begin{array}{l}235 \\
189 \\
153 \\
221 \\
273\end{array}$ & $\begin{array}{l}365 \\
298 \\
239 \\
342 \\
423\end{array}$ \\
\hline $\begin{array}{l}\text { Keksu } \\
\text { Kash } \\
\text { Kunes } \\
\text { Tekes } \\
\text { Ily }\end{array}$ & $\begin{array}{l}-1463 \\
-1649\end{array}$ & $\begin{array}{r}-814 \\
-914 \\
-790 \\
-1066\end{array}$ & $\begin{array}{l}-529 \\
-590 \\
-483 \\
-512 \\
-695\end{array}$ & $\begin{array}{l}-325 \\
-363 \\
-285 \\
-313 \\
-429\end{array}$ & $\begin{array}{r}-164 \\
-177 \\
-1456 \\
-155 \\
-212\end{array}$ & $\begin{array}{r}-8 \\
-9 \\
-8 \\
-8 \\
-11\end{array}$ & $\begin{array}{l}136 \\
152 \\
126 \\
129 \\
186\end{array}$ & $\begin{array}{l}277 \\
305 \\
265 \\
260 \\
383\end{array}$ & $\begin{array}{r}435 \\
477 \\
392 \\
406 \\
612\end{array}$ \\
\hline Kaidu & -1207 & -669 & -432 & -265 & -129 & -7 & 112 & 222 & 350 \\
\hline Sairan & -1170 & -648 & -418 & -256 & -125 & -7 & 107 & 213 & 334 \\
\hline
\end{tabular}


observed glaciers are available to test the calculated values of mass balance. The values for large areas could be tested by data from the repeated topographic surveys, but these were carried out only on separate glaciers or groups of glaciers, not for the whole Tien Shan.

\section{REFERENCES}

Academia Sinica. 1986 87. [Glacier inventory of China III. Tien Shan Mountains.] Lanzhou, Lanzhou Institute of Glaciology and Cryopedology. [In Chinese.]

Akademii Nauk SSSR. 1969-78. Katalog lednikov SSSR [Inventory of glaciers of the USSR ], 13(2), Parts 1-3; 14(1), Parts 1-11. Leningrad, Gidrometeoizdat.

Dyurgerov, M. B. 1986. Raschet balansa massy lednikovykh sistem/Computations of mass balance in glacier systems. Mater. Glyatsiol. Issled. 57, 8-15 (Russian); 144-148 (English).

Dyurgerov, M. B., M. G. Kunakhovich, V. N. Mikhalenko, A. M. Sokals- kaya and V. A. Kuzmichenok. 1992. Can the mass balance of the entire glacier area of the Tien Shan be estimated? Ann. Glaciol., 16, 173-179.

Getker, M. I. 1985. [Snow resources of mountains in Central Asia.] (D.Sc. thesis, Institute of Geography, Moscow.) [In Russian.]

Khodakov, V. G. 1965. O zavisimosti summarnoy ablyatsii poverkhnosti lednikov ot temperatury $v$ vozdukha [Relationship between the sum of ablation of the glacier surface and air temperature]. Meteorol. Gidrol., 7, 48-50.

Krenke, A. N. and V. M. Menshutin. 1987. Calculation of mass balance of glaciers by remote-sensing imagery using similarity of accumulation and ablation isoline patterns. 7. Glaciol., 33(115), 363-368.

Kuhn, M., G. Markl, G. Kaser, U. Nickus, F. Obleitner and H. Schneider. 1985. Fluctuations of climate and mass balance: different responses of two adjacent glaciers. Z. Gletscherkd. Glazialgeol., 21, 409-416.

Kunakhovitch, M. G. 1991. [Mountain glacier mass balance: similarity and numerical computation.] (Ph.D. thesis, Institute of Geography, Moscow.) [In Russian.]

Kuzmichenok, V. A. 1993. Ledniki Tyan'-Shanya. Komp'yuternyy analiz kataloga [The glaciers of Tyan'-Shan'. Computerized analysis of the inventory]. Mater. Glysatsiol. Issled. 77, 2941. 